\title{
ECONOMIC DIVERSIFICATION ON SMALL AGRICULTURAL HOLDINGS
}

\author{
Aina Dobele ${ }^{1}$, Dr.oec.; Andra Zvirbule², Dr.oec.; Vineta Pece ${ }^{3}$, Mg.oec. \\ 1,2 Latvia University of Life Sciences and Technologies, ${ }^{3}$ Jelgava Municipality
}

\begin{abstract}
In Latvia, small agricultural holdings comprise a very high proportion of the total agricultural holdings - $90 \%$. However, their number decreases, which is caused by a decline in their competitiveness and insufficient cash flow. Nevertheless, such holdings play an essential role in rural development in Latvia. One of the main problems to be tackled is the identification of new business paths for the holdings, i.e. their business diversification. The research aim is to identify prerequisites for economic diversification for small agricultural holdings in North Kurzeme. The research revealed that small agricultural holdings used mainly their own funds and less relied on external finance, which could be a hindering factor for their development. In the opinion of agricultural holding owners, the diversification of their holdings is strongly associated with consumer purchasing power, and higher profits have to be the result of the diversification.
\end{abstract}

Key words: small agricultural holdings, diversification, diversification factors.

JEL code: Q12

\section{Introduction}

Nowadays, an idea is popularised that the future production of food and other products could be only industrial, large-scale and uniform. Nevertheless, according to the Central Statistical Bureau of Latvia, small agricultural holdings, in terms of utilised agricultural area and standard output, accounted for $90 \%$ of the total in Latvia. The number of such holdings declined year by year; therefore, the retention and development of small and medium agricultural holdings in rural areas in Latvia is an important matter. The insolvency and liquidation of small agricultural holdings can only increase the number of poor families, depopulation and unemployment in rural areas and in Latvia as a whole.

In view of the above, it is necessary to seek solutions to ensure continuous operation of small agricultural holdings, stabilise their cash flows and improve their competitiveness. Economic diversification is a way to increase the viability and competitiveness of small agricultural holdings. The research puts forward a hypothesis: the economic diversification of small agricultural holdings is affected by both endogenous and exogenous factors. A survey of small agricultural holdings was conducted in the northern part of Kurzeme region. The research aim is to identify prerequisites for economic diversification for small agricultural holdings in North Kurzeme. To achieve the aim, the following research tasks were set: 1) to characterise the theoretical aspects of economic diversification; 2) to examine the factors affecting the economic diversification of small agricultural holdings and the significance of the factors in North Kurzeme.

Along with general research methods - abstract and logical analysis, content analysis, monographic and graphic - the following sociological research methods were employed: expert evaluation, surveying and individual interviewing. The survey represented closed-ended questions, except for one open-ended one in which respondents had an opportunity to explain their opinions. A nominal scale, the Likert scale and the semantic differential scale (to measure agreement about an assertion etc.) were employed for closed-ended questions.

\section{Research results and discussion}

\section{Nature and kinds of economic diversification}

An economic and financial dictionary (2003) explains the term diversification as "a strategy of an organisation to start up business in another industry alongside the current business, thereby attracting new customers". The academic term database AkadTerm (s.a.) defines diversification as 
"the expansion of the scope of business and of the range of products, which is usually done when an enterprise has no opportunity to grow in the current field of activity or another kind of economic activity is more advantageous (i.e. offering higher profits)" (Diversifikacija (s.a.).

The association of diversification with the development of new products is stressed by A. Coleman (Coleman, 2013) and W.Craig (Craig, 2015); in their works, both authors attribute diversification to the creation of new products, an examination of and entry into new markets and the assumption of new risks.

Diversification is explained also as the reallocation and recombination of farm resources away from its original farming activity to generate another form of income (Meraner, 2014).

Authors J. Cornwall and B. Perlman (Cornwall, Perlman, 1990) and V. Praude (2012) distinguish three kinds of diversification:

- concentrated diversification - if an enterprise broadens its range of products by similar products; the new products are intended for a new range of consumers;

- horizontal diversification - if an enterprise begins producing new kinds of products that help to attract consumers; the products are intended for both the present and new customers of the enterprise;

- conglomerate diversification - if an enterprise adds new products that are completely new ones and that are unrelated to the present products; consequently, the enterprise has more customers.

J. Caune and A. Dzedons (2009), T. Volkova, B. Aneraude and others (2010) define diversification as the expansion of activity of an enterprise through engaging in new fields of economic activity, yet this basic strategy is divided into two kinds: related and unrelated diversification.

A different perspective, which relates to the economic activity of an enterprise and its diversification is given by A.Coleman (Coleman, 2013) and I.Meraner (Meraner, 2014). A. Coleman (Coleman, 2013) believes that diversification could be both a specially designed process and natural business expansion. However, according to I.Meraner (Meraner, 2014), diversification could be characterised by four activities that can be performed by a farm that is engaged in conventional farming and wishes to diversify its business (Table 1).

Table 1

\section{Characteristics of diversification activities}

\begin{tabular}{|l|l|}
\hline \multicolumn{1}{|c|}{ Name of activities } & \multicolumn{1}{c|}{ Characteristics of activities } \\
\hline "On-farm sale" & Small shops on farms, roadside stalls, fruit and berry self-picking etc. \\
\hline $\begin{array}{l}\text { "On-farm } \\
\text { processing" }\end{array}$ & Crafts, processing of berries, fruits and vegetables etc. \\
\hline "Agrotourism" & $\begin{array}{l}\text { Accommodation services (campsites, tent places), active recreation, catering services, } \\
\text { animal farm visits etc. }\end{array}$ \\
\hline "Care farming" & $\begin{array}{l}\text { The purpose of care farming services is the education, care, integration and } \\
\text { rehabilitation of vulnerable persons, pensioners and children. }\end{array}$ \\
\hline
\end{tabular}

Source: authors' construction based on Meraner, 2014

Economic diversification and farm multifunctionality is a focus and an integral part of the EU Common Agricultural Policy aimed at avoiding a crisis under the agricultural pattern, the main priority of which is to contribute to agricultural output. The CAP, stressing the opportunity for farms to diversify their economic activity and to become multifunctional, raises the farms' interest in mitigating climate change through changing their agricultural practices that are environment- 
friendlier and engaging, for example, in organic farming. Such a change of the policy paradigm encourages farm owners to do their business in a different way - to diversify it, to engage in other kinds of economic activity - in order to, for example, acquire European Union funding for their farm development (Meraner, 2014).

The explanations of diversification given by various authors allow concluding that the key priorities are the viability of farms, higher farm profits and risk reduction for the farms. However, opinions about the need for the economic diversification of farms are diverse. W. Craig (Craig, 2015) believes that diversification is necessary for some enterprises, whereas the others are not going to benefit from it. Diversification can ensure stable operation of an enterprise, yet it involves some risks. In the financial sector, diversification allows reducing risks, i.e. if a negative event occurs, all the investments might be lost. In the market of goods and services, which is volatile, the business operations done by other enterprises could be unpredictable, and any business is regularly affected by changing consumer needs; therefore, diversification can give the enterprise an opportunity to implement new, innovative ideas and enter new markets. W. Craig (Craig, 2015) points out that some enterprises, doing diversification repeatedly, come to conclusions regarding what to produce and how to do it more efficiently.

M. Meraner (Meraner, 2014) points out that a decision on economic diversification is usually made in order to survive in the market because of volatile yields and prices. Besides, the farms that have diversified their business, are more responsive to any change in demand and in consumer wishes, which allows them make higher profits.

I. Weltin and others (Weltin et al., 2016) have focused on other factors that affect a decision to do economic diversification. According to them, there are two decisive factors influencing farmer decisions to diversify the source of revenue:

- main business of the farm;

- family structure.

Farms owned and managed by young households as well as by large households more frequently make a decision to diversify their business, as the risk of labour shortage is lower as well as the young individuals are interested in making their own efforts and develop their farms. In contrast, farms owned and managed by older households or by small households are not interested in diversification because of the shortage of labour and they have difficulties to generate sufficient synergy effects (Weltin, 2016).

\section{Economic diversification on small agricultural holdings in North Kurzeme}

To accurately describe and assess the factors affecting decisions on the economic diversification of agricultural holdings as well as to identify the attitudes to and opinions of agricultural holding owners on the diversification, the research conducted, first, a survey and, second, individual interviews. The study involved a broad spectrum of agricultural holdings in terms of age of owners, kind of activity and economic size.

The survey participants were owners of small agricultural holdings in North Kurzeme. Their age was diverse: $18-25$ (18\%), 26-44 (18\%) and 45-64 (64\%). Farming was the main job for $82 \%$ of the respondents, while off-farm employment was the main job for $18 \%$. The agricultural holdings analysed were engaged in diverse activities: beef cattle production (19\%), fruit production $(15 \%)$, organic farming $(9 \%)$ and milk production $(11 \%)$, while mixed farming represented $46 \%$. 
An analysis of the agricultural holdings in terms of net turnover revealed that the holdings with a turnover of EUR 3001-6000 (37\%) dominated, followed by those with a turnover of less than EUR $3000(27 \%)$, while the holdings with turnovers of EUR 6001-10000 and more than EUR 10000 represented $18 \%$ each.

An opportunity to borrow funds is an essential factor for farm development, which could also contribute to farm diversification. The sources of finance indicate the ability of farm owners to assume financial risks as well as their trust in financial institutions.

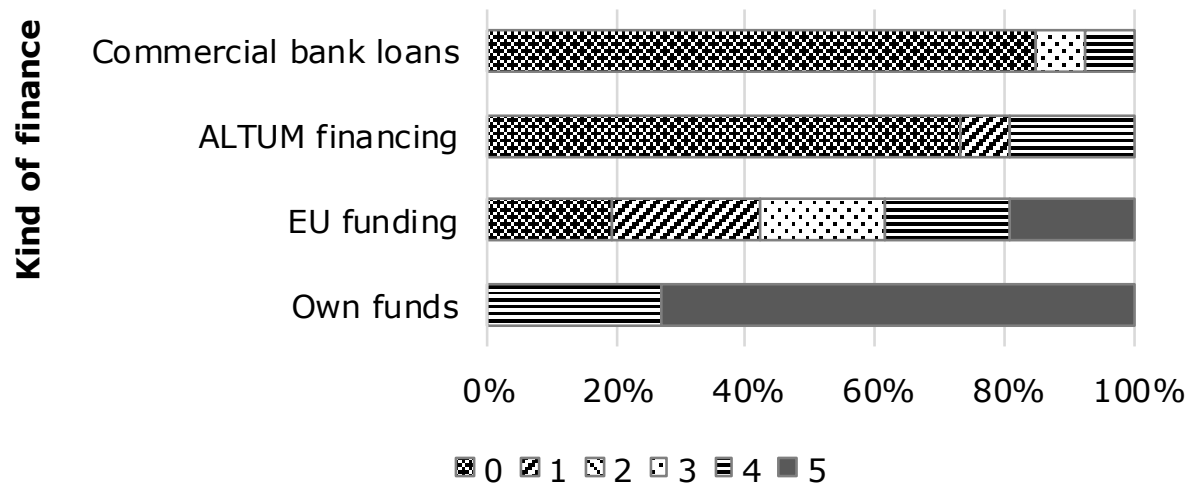

Source: authors' construction

Fig. 1. Percentage breakdown of the ratings of financial resources used by small agricultural holdings for business ( 0 - the lowest, 5 - the highest)

The survey data acquired revealed that most of the holdings used internal sources of finance or their own funds for their business development, and the significance of their own funds was rated the highest. As regards external sources of finance - commercial bank loans and ALTUM financing - the significance of the sources was rated the lowest (bank loans and ALTUM financing were rated at 0 by $82 \%$ and $73 \%$ respondents, respectively), which indicated the tendency of holding owners avoid assuming financial obligations. The significance of EU funding was rated differently. Breaking down the data by significance of financial resources and by type of agricultural holdings revealed that the holdings that were engaged in rural tourism, poultry production and bee-keeping rated EU co-funding low, yet the holdings that were engaged in organic farming, milk production, beef cattle production and fruit production rated the EU co-funding very high ( 4 and 5 points), which might be explained by the diversity of kinds of available financial support and the amount of the support for the mentioned kinds of holdings in particular.

The key purpose of the survey was to identify the main factors affecting decisions made by agricultural holdings on the diversification of their business. Every respondent had to rate the effect of every factor on a scale from 1 to 4 : "no effect" (1); "insignificant effect" (2); "moderate effect" (3); "significant effect" (4). 


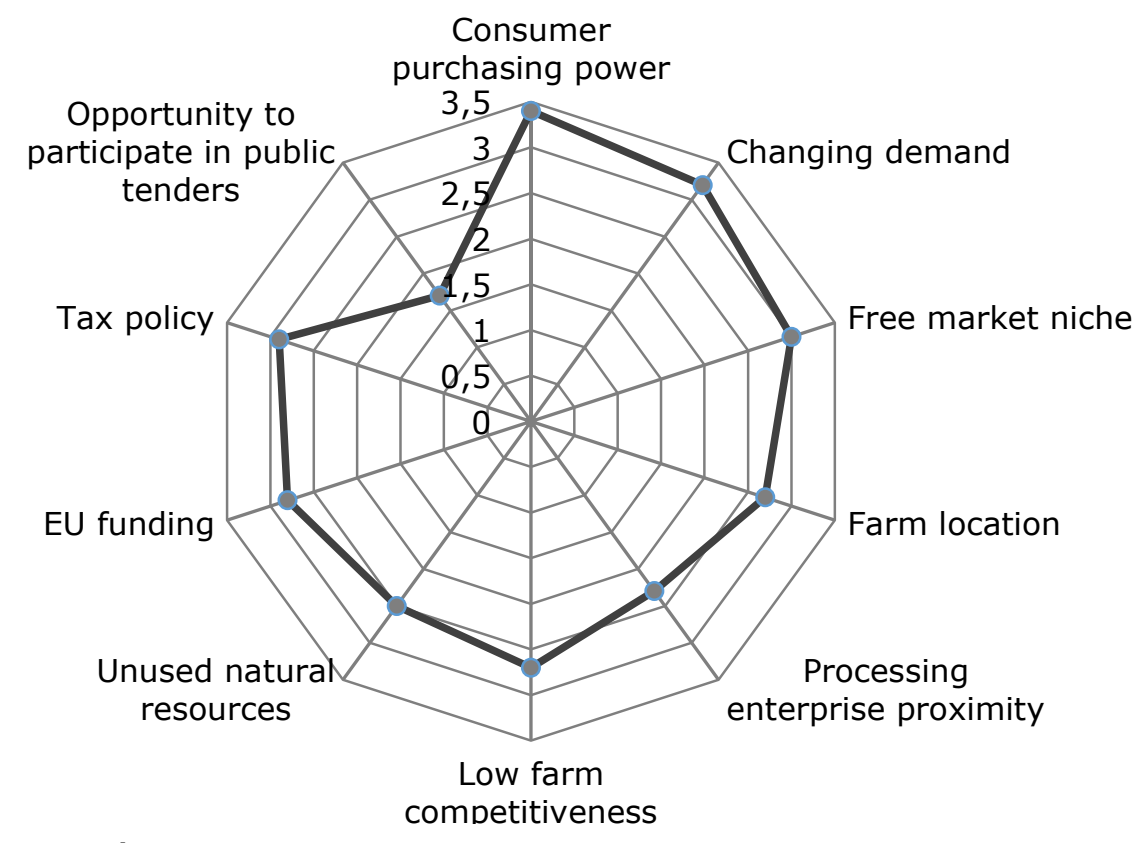

Source: authors' construction

competitiveness

\section{Fig. 2. Ratings of exogenous factors affecting economic diversification on small agricultural holdings}

An aggregation of the data on every exogenous factor revealed that the decisions to diversify business were mainly affected by consumer purchasing power (3.4), volatile demand (3.2), a free market niche (3.0) and tax policy (2.9). This indicates that the holding managers associated their business development with the standard of living of the population and the national development level.

The data on endogenous factors showed that the decisions on business diversification were mainly affected by an opportunity to expand the business (3.9), earn higher profits (3.3) and distribute risks (2.8).

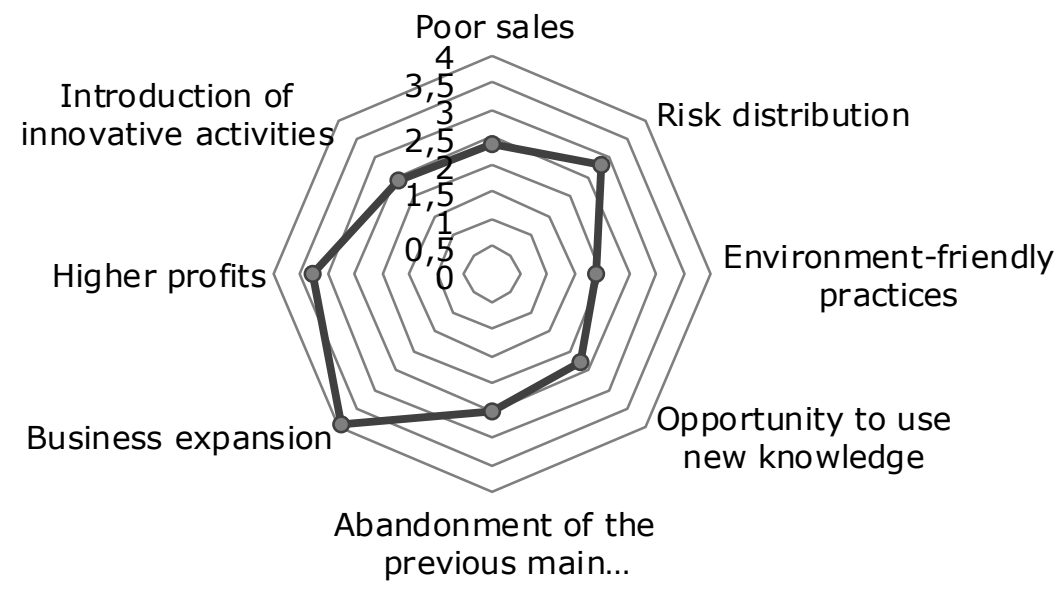

\section{Source: authors' construction}

\section{Fig. 3. Ratings of endogenous factors affecting economic diversification} on small agricultural holdings

The study revealed that the most important reason of diversification was the wish to expand business; therefore, the study sought to identify the business expansion paths. 


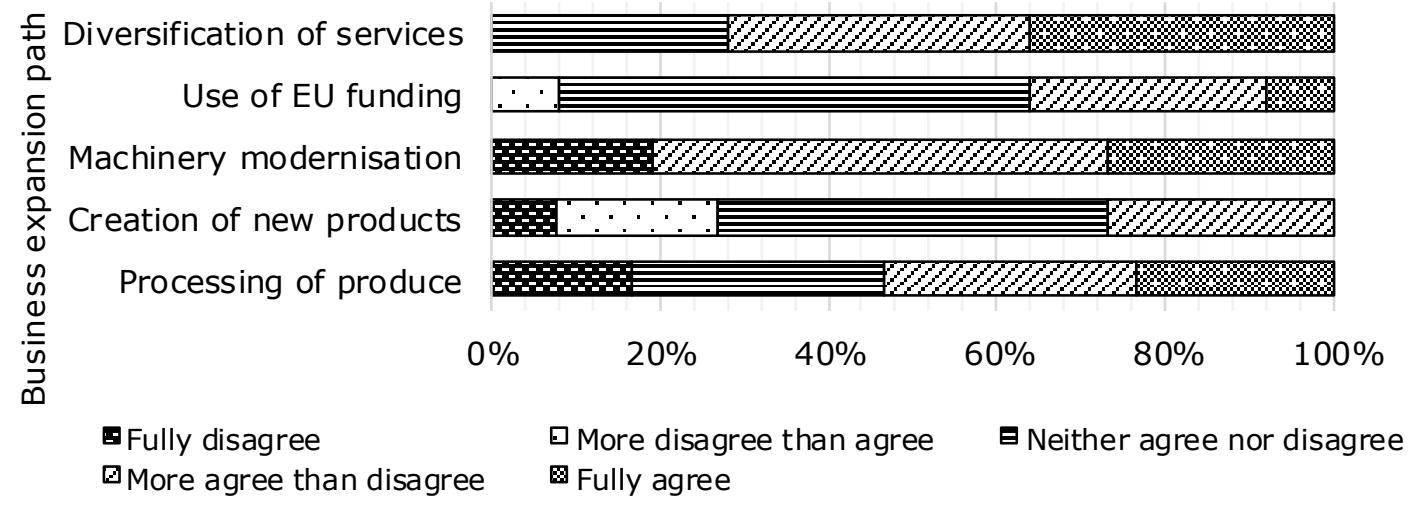

Source: authors' construction

Fig. 4. Percentage breakdown of the ratings of farm diversification paths for small agricultural holdings

The most popular business expansion paths, according to the respondents, were diversification of services and machinery modernisation, while processing of agricultural products was less popular. Use of EU funding was not a decisive prerequisite for business expansion.

Grouping and an analysing the agricultural holdings by kind of economic activity and by future business expansion path allows concluding that the holdings engaged in fruit and vegetable production and rural tourism preferred diversification of services and processing of agricultural products, while the holdings planning to modernise their machinery were engaged in milk, beef cattle and pig production and provision of agricultural machinery services, as modernised machinery allows saving time and facilitating some technological operations in the mentioned kinds of business.

The respondent opinions on whether economic diversification was the only opportunity to ensure the viability of small agricultural holdings differed. Of the respondents, $46 \%$ believed that diversification was the only way how to make small agricultural holdings viable, and the same percentage of them ( $46 \%$ ) considered that no diversification was necessary. However, $8 \%$ chose the reply option "other", adding that business could be diversified based on a feasibility study and if there is demand for new products and services.

An aggregation and an analysis of the respondent opinions on the need for diversification allowed identifying the profile of the holdings (Table 2 ).

Table 2

\section{Profile of agricultural holdings according to the respondent opinions on the need for diversification}

\begin{tabular}{|c|c|}
\hline Agricultural holdings favouring business diversifification & $\begin{array}{l}\text { Agricultural holdings not } \\
\text { favouring business } \\
\text { diversifification }\end{array}$ \\
\hline - experienced farm owners aged $45-64$; & $\begin{array}{l}\text { - farm turnover from EUR } 6001 \text { to } \\
10000\end{array}$ \\
\hline - farm turnover from EUR 3001 to 6000 ; & $\begin{array}{l}\text { - business focuses on miikand beef } \\
\text { production; }\end{array}$ \\
\hline $\begin{array}{l}\text { - business focuses on rurai tourism, organic farming, fruit } \\
\text { production, pouitry and pig production, agricuiturai } \\
\text { machinery services; }\end{array}$ & $\begin{array}{l}\text { - most important financiai resources: } \\
\text { own funds and EU co-funding. }\end{array}$ \\
\hline $\begin{array}{l}\text { - most important financiai resource is } \\
\text { own funds. }\end{array}$ & \\
\hline
\end{tabular}

Source: authors' construction 
The data allow concluding that the opinions of the holding owners about the diversification of their business depend on the kind of their economic activity, which affects the turnover of their holdings, and on the amount and diversity of EU co-funding received. The holdings with a turnover of less than EUR 6000 were engaged in the kinds of economic activity where the consumer was the most important factor, which affected the volume of sales and the quantity of unsold products as well as the stability of demand; the small agricultural holdings (which participated in the survey) did not and could not sufficiently use EU co-funding that could raise the stability of their business.

In contrast, the agricultural holdings that were engaged in milk and beef cattle production and in other kinds of economic activity offering a greater opportunity to receive various kinds of EU co-funding and that sold their products to agricultural processors assigned a greater role to the tax policy and the modernisation of machinery.

\section{Conclusions, proposals, recommendations}

1) By diversifying their business, agricultural holdings identify and create new solutions to inefficient resource use, which might result in innovations that optimise costs, enhance farm performance as well as lead to a new specialisation. Innovations might be developed within the agricultural holding and on a broader scale.

2) Among the exogenous factors, the most important factors influencing decisions on economic diversification are as follows: consumer purchasing power, volatile demand, a free market niche, the standard of living and tax policy, while most important endogenous factors are an opportunity for business expansion, higher profits and risk distribution.

3) According to the survey, the opinions of owners of agricultural holdings on the diversification of their business depended on the kind of their economic activity, which affected the turnover of the agricultural holdings, and on the amount of EU co-funding received.

\section{Bibliography}

1. Atbalsts uznemejdarbibas uzsaksanai, attistot mazas lauku saimniecibas (2017). Lauku atbalsta dienests (Support for Starting up Business by Small Agricultural Holdings. Rural Support Service). Retrieved: http://www.lad.gov.Iv/lv/atbalsta-veidi/projekti-un-investicijas/atbalsta-pasakumi/6-3-atbalstsuznemejdarbibas-uzsaksanai-attistot-mazas-lauku-saimniecibas-221. Access: 31.03.2017.

2. Caune, J., Dzedons, A. (2009) Strategiska vadisana. Otrais izdevums (Strategic Management. Second Edition). Riga: Lidojosa zivs. p. 384.

3. Coleman, A. (2013). Diversify or Die: Explore New Markets and Help Your Business Grow: The Guardian. Retrieved: https://www.theguardian.com/small-business-network/2013/jun/14/diversify-die-explore-newmarkets-business-grow. Access: 10.01.2017.

4. Cornwall, J., Perlman, B. (1990). Organizational Entrepreneurship. The United States of America: Richard D.Irwin, INC. p. 241.

5. Craig, W. (2015). Business Diversification: the Risk and the Reward: Forbes Media LLC. Retrieved: http://www.forbes.com/sites/williamcraig/2015/04/24/business-diversification-the-risk-and-thereward/2/\#5700e36635b3. Access: 08.01.2017.

6. Diversification (s.a.). Business Dictionary.

Retrieved: http://www.businessdictionary.com/definition/diversification.html. Access: 08.01.2017.

7. Diversifikacija (s.a.). Academic Term Database AkadTerm. Retrieved: http://termini.Iza.Iv/term.php?term=diversifik \%C4 \%81cija\&list=diversifik \%C4 \%81cija\&lang= LV. Access: 08.01.2017.

8. Future of Small Farms (2014). European Parliamentary Research Service Blog. Retrieved: https://epthinktank.eu/2014/02/15/future-of-small-farms/. Access: 31.05.2016.

9. Haines, M., Davies, R. (1987) Diversifying the Farm Business: A Practical Guide to the Opportunities and Constraints. Oxford: BSP Professional Books. p. 304.

10. Linton, I. (2015). Product Diversification Strategy. Retrieved: http://smallbusiness.chron.com/productdiversification-strategy-40375.html. Access: 11.01.2017.

11. Meaning of "farm" in the English Dictionary (s.a.). Cambridge Dictionary.

Retrieved: http://dictionary.cambridge.org/dictionary/english/farm. Access: 23.03.2017. 
12. Meraner, M., Heijman, W., Kuhlman, T. (2014). Determinants of Farm Diversification in the Netherlands. Science Direct.

Retrieved:http://www.sciencedirect.com.ezproxy.llu.Iv/science/article/pii/S0264837714002300.

Access: 10.01.2017.

13. Product Diversification (s.a.). Business

Dictionary. Retrieved: http://www.businessdictionary.com/definition/product-diversification.html.

Access: 15.04.2017.

14. The Importance of Diversification (2016). Investopedia.

Retrieved: http://www.investopedia.com/articles/02/111502.asp. Access: 08.01.2018.

15. Van der Ploeg, J.D., Laurent, C., Blondeau, F. (2009). Farm Diversity, Classification Schemes and Multifunctionality. Science Direct.

Retrieved: http://www.sciencedirect.com.ezproxy.llu.Iv/science/article/pii/S0301479708003472. Access: 10.01.2018.

16. Volkova, T., Aneraude, B., Eglitis, U., Grinbergs, A. u.c. (2010). Bizness pari robezam: Praktisks celvedis jaunu tirgu apgusana (Business beyond Borders: a Practical Guide to Enter New Markets). Riga: LU Akademiskais apgads. p. 184.

17. Weltin, M., Zasadaa, I., Frankeb, C., Piorra, A., Raggic, M., Viaggi, D. (2016). Analysing Behavioural Differences of Farm Households: An Example of Income Diversification Strategies based on European Farm Survey Data. Science Direct. Retrieved: 1-s2.0-S0264837716300552-main.pdf. Access: 15.01.2018. 